\title{
An estimation of the frequency of gestational toxoplasmosis in the Brazilian Federal District
}

\author{
Contribuição para a estimativa da freqüência de toxoplasmose \\ em gestantes do Distrito Federal
}

\author{
Otávio de Tolêdo Nóbrega ${ }^{1,2}$ and Margô Gomes de Oliveira Karnikowski ${ }^{1,2}$
}

\begin{abstract}
Acute infections by the protozoan Toxoplasma gondii during pregnancy (gestational toxoplasmosis) are known to cause serious health problems to the fetus ( congenital toxoplasmosis). In Brasília, there have been few studies on the incidence of toxoplasmosis. This report summarizes a retrospective study performed on 2,636 selected pregnant women attended by the public health system of Guará, a satellite-City of Brasília. In this survey, 17 cases of gestational toxoplasmosis were detected; 15 of which were primary maternal infection and the remaining 2 were consistent with secondary maternal infection. These results suggest an annual seroconversion rate of 0.64 percent ( 90 percent confidence interval: 0.38 , 0.90).
\end{abstract}

Key-words: Toxoplasma. Gestational toxoplasmosis. Morbidity. Federal District. Brazil.

\section{RESUM0}

Infecções agudas pelo protozoário Toxoplasma gondii durante a gravidez (toxoplasmose em gestantes) são conhecidas por causar sérios problemas de saúde ao feto (toxoplasmose congênita). Em Brasília, estudos sobre a incidência da toxoplasmose são escassos. Este relato resume um estudo retrospectivo realizado com um grupo selecionado de 2.636 gestantes assistidas pelo sistema público de saúde do Guará, Cidade-satélite de Brasília. Nesta investigação, foram detectados 17 casos de toxoplasmose gestacional; 15 dos quais casos de infecção materna primária, e os 2 restantes consistentes com infecção materna secundária. Estes resultados sugerem uma taxa de soroconversão anual da ordem de 0,64 porcento (intervalo de confiança de 90 porcento: 0,38; 0,90).

Palavras-chaves: Toxoplasma. Toxoplasmose gestacional. Morbidade. Distrito Federal. Brasil.

Toxoplasmosis is caused by infection with the protozoan parasite Toxoplasma gondii. Acute infections acquired during pregnancy (gestational toxoplasmosis) are known to cause serious health problems when the microorganism is transmitted to the fetus (congenital toxoplasmosis), including ocular and neurological sequels, seizures, blindness and death ${ }^{1}$. Nonetheless, manifestations of congenital toxoplasmosis may not become apparent until the second or third decades of life $^{2}$. In Brazil, official statistics from the Ministry of Health (http:// tabnet.datasus.gov.br/cgi/sim/obtmap.htm) state that toxoplasmosis alone is responsible for on average 90 deaths a year. However, there is a lack of data on the morbidity posed by this zoonosis. Several studies ( reviewed by Camargo) ${ }^{1}$ have shown that 50 to $80 \%$ of all Brazilian women in childbearing age exhibit IgG antibodies to T. gondii. Therefore, 20 to $50 \%$ are susceptible to this infection. In various states of the Country, serological surveys have confirmed steady rates of infection during pregnancy: for instance 1.7\% and 1.8\% in the states of Santa Catarina ${ }^{2}$ and Paraná, respectively 5 .

In Brasilia, denomination of the metropolitan region that comprises the Brazilian capital city, statistics on the incidence of toxoplasmosis are generally scarce or dispersed. Only the regional public Health System of Taguatinga, a satellite-city in the outskirts of Brasilia, releases data regularly on the total

1. Center for Studies in Health Sciences at the University of Brasília, Brasília, DF, Brazil. 2. Pharmacy College at the Catholic University of Brasília, Brasília, DF, Brazil. Address to: Dr. Otávio de T. Nóbrega. Pró-Reitoria de Graduação/Curso de Farmácia. Q.S. 07, Lote 01, EPCT, Águas Claras, $72030-170$ Brasília, DF, Brasil.

Tel: 5561 356-9693, Fax: 5561 356-3010.

e-mail: nobrega@pos.ucb.br.

Recebido para publicação em 7/1/2004

Aceito em 8/5/2005 
number of cases notified in that area, that totaled 46 cases in the first semester of year 2000 ( http://www.saude.df.gov.br/saude/ 11not11b.asp). Unfortunately, cases of congenital or gestational toxoplasmosis are not currently assessed. In this scenario, elaborating epidemiologic surveys and determining expectancy rates mightaid in the implantation of targeted prenatal education and newborn screening strategies with the goal of preventing morbidity associated with the disease.

In this report, we presentresults of a pilotstudy that provided an estimation of the frequency of gestational toxoplasmosis in the satellite-city of Guará, located within the geo-economical limits of the Brazilian Federal District. For that purpose, a retrospective study was performed investigating serologic records of pregnant women admitted from January to December 2000 in prenatal programs of the public regional hospital of Guará (HRGu) and the 3 public health centers of that city. This investigation was conducted by screening individual medical records for indication of gestational toxoplasmosis among the women studied. Taking into account that: i) most women are submitted to prenatal tests for toxoplasma-specific IgG and IgM whenever admitted to prenatal follow up, and those susceptible are re-tested on a bimonthly basis, and ii) the diagnostic procedures for toxoplasmosis in the regional public health system are standardized, using enzyme-linked immunosorbent assay (ELSA) as described by Camargo ${ }^{1}$, a total of 2,636 pregnancies were selected that presented IgM and IgG levels < 1:64.

Infection during pregnancy was identified based on the occurrence of maternal seroconversion according to the following independent criteria: 1) detection of specific IgM in dilutions $\geq 1: 64$, or 2) a minimum four-fold rise in the specific IgG levels in comparison with the titer stated on the woman's former test. For this study, a case was considered positive whenever a following confirmatory test (i.e. repetition) was present in the woman's record. Considering the group studied, the criteria above are consistent with active toxoplasmosis ${ }^{16}$, characterizing primary and secondary gestational toxoplasmosis, respectively. Statistical analysis was performed determining the confidence interval for each estimation, setting the level of confidence at 90 percent $(z=1.65)$.

Based on the above criteria, 17 cases of gestational toxoplasmosis were found within the universe of pregnancies studied, of which 15 were diagnosed by specific IgM antibodies against T. gondii, amounting to $0.57 \%$ ( $90 \%$ confidence interval (CI) : $0.34,0.80)$ of primary maternal infection. The two remaining cases were diagnosed by the four-fold IgG increase criterion, giving $0.08 \%$ ( $90 \%$ CI: $0.01,0.15)$ secondary maternal infection. Taken together, these results suggest an overall seroconversion rate of 0.64 percent ( $90 \%$ CI: $0.38,0.90$ ). The data above is summarized in Table 1. As this was a preliminary study, the influence of factors such as age, ethnicity or socialeconomical group were not considered.

In summary, our results reveal that the frequency of primary toxoplasma infection among pregnant women $(0.57 \%)$ is relatively low in our region when compared to states such as Santa Catarina ( 1.7 percent) and Paraná (1.8 percent), this being nonetheless noteworthy, since it significantly exceeded the
Table 1 - Individual cases of gestational toxoplasmosis (absolute number) and seroconversion rates (percentage) for primary and secondary infections found among the 2,636 pregnancies studied.

\begin{tabular}{lcc}
\hline Index/Status & Cases & Seroconversion rate \\
\hline Primary infection & 15 & $0.57 \%$ \\
Secondary infection & & $(90 \%$ CI: $0.34,0.80)$ \\
& 2 & $0.08 \%$ \\
\hline Total & & $(90 \%$ CI: $0.01,0.15)$ \\
& 17 & $0.64 \%$ \\
& & $(90 \%$ CI: $0.38,0.90)$ \\
\hline
\end{tabular}

90\% CI - 90 percent confidence interval

frequency of secondary infection $(\mathrm{P}<0.001)$ and accounted for $88.2 \%$ of the seroconversion occurrences identified in the present study.

Although our results do notallow precise determination of the prevalence of congenital toxoplasmosis, expectancy rates are usually helpful for implementing public health policies for infectious diseases. Taking into account that 46,500 live newborns were delivered at the capital's public health system in the year 2000 (http:// www.saude.df.gov.br/download/dados estatisticos.zip), the incidence of primarymaternal infection was extrapolated to estimate a frequency of gestational toxoplasmosis raging from 3.4 to 8 per 1,000 live births thatyear. It is important to consider that $80 \%$ of all cases of primary toxoplasmosis in pregnancy result in ocular lesion or late neurological disorders in the child ${ }^{2}$. Therefore, our results suggest a yearly average of 212 children at risk for developing sequels from primary maternal toxoplasma infection. Unfortunately, our estimation probably underestimates the total number of newborns carrying the congenital form of the disease in Brasília, since this work was based on data from the public health system only, without considering pregnancies attended by the regional private health system. In addition, a stringent cutoff limit was set in order to minimize inclusion of false-positive cases or borderline results. Furthermore, even though a socialeconomical analysis was not included, it should be considered that the city of Guará may not accurately represent the entire Federal District, since the outskirts are generally recognized to have lower standards of sanitary infrastructure. Future assessments on the seroconversion rate among pregnant wo men resident in such areas would help increase the accuracy of the estimation determined in this study, which may feature from now on as a referential index on the status of the toxoplasmosis issue in the Brazilian Federal District and in Brazil as a whole.

The incidence of gestational toxoplasmosis varies greatly between regions, but is recognized to be widely distributed throughout the globe. The practice of routine serologic screening for maternal toxoplasma infection in countries such as France and Austria has proven to greatly reduce the incidence of the congenital form of the disease ${ }^{6}$. In Brazil, such practice is not generally implemented, due in part from failure to enforce legal obligations. Consequently much data on the incidence of toxoplasmosis is unavailable. Such a lack of screening for onset of congenital toxoplasmosis predisposes countless newborns throughout the Country to development of late consequences, which could have been minimized by an early postnatal intervention. 


\section{ACKNOWLEDGEMENTS}

The authors are greatly indebted to Dr. Rosane Santos Grisolia, from the Regional Laboratory of Guará, for her advisory role on technical issues and interpretation of results. The authors also thank the University of Brasília for assistance in the development of this study.

\section{REFERENCES}

1. Camargo ME. Toxoplasmosis. In: Ferreira AW, Ávila SLM ( eds) Diagnóstico laboratorial das principais doenças infecciosas e auto-imunes, Editora Guanabara-Koogan, Rio de Janeiro, p. 165-174, 1996.
2. Cantos GA, Prando MD, Siqueira MV, Teixeira RM. Toxoplasmose: ocorrência de anticorpos anti-Toxoplasma gondii e diagnóstico. Revista da Associação Médica Brasileira 46: 335-341, 2000.

3. Jones JL, Lopez A, Wilson M, Schulkin J, Gibbs R. Congenital toxoplasmosis: a review. Obstetrical and Gynecological Survey 56: 296-305, 2001.

4. Koppe JG, Loewer SDH, Roever BH. Results of 20 years follow-up on congenital toxoplasmosis. Lancet 1: 254-256, 1986.

5. Reiche EMV, Morinoto HK, Farias GN, Hisatsugu KR, Geller L, Gomes ACLF, Inoue HY, Rodrigues G, Matsuo T. Prevalência de tripanossomíase americana, sífilis, toxoplasmose, rubéola, hepatite $\mathrm{B}$, hepatite $\mathrm{C}$ e da infecção pelo vírus da imunodeficiência humana, avaliada por intermédio de testes sorológicos, em gestantes atendidas no período de 1996 a 1998 no Hospital Universitário Regional Norte do Paraná. Revista da Sociedade Brasileira de Medicina Tropical 33: 519-527, 2000.

6. Wong SY, Remington JS. Toxoplasmosis in pregnancy. Clinical and Infectious Diseases 18: 853-862, 1994. 